\title{
Article
}

\section{Detection of Haplosporidium pinnae from Pinna nobilis Faeces}

\author{
Raquel Lopez-Nuñez ${ }^{1, * \mathbb{D}}$, Emilio Cortés Melendreras ${ }^{2} \mathbb{D}$, Francisca Giménez Casalduero ${ }^{1,3} \mathbb{D}^{\mathbb{D}}$, Patricia Prado $^{4} \mathbb{D}$,

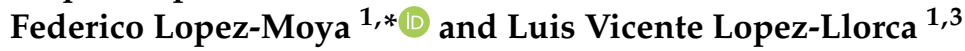

1 Department of Marine Science and Applied Biology, University of Alicante, 03690 Alicante, Spain; francisca.gimenez@ua.es (F.G.C.); lv.lopez@ua.es (L.V.L.-L.)

2 IMEM, Ramón Margalef Institute, University of Alicante, 03690 Alicante, Spain; ecortes@um.es

3 Murcia University Aquarium, University of Murcia, 30002 Murcia, Spain

4 IRTA-Sant Carles de la Ràpita. Ctra. Poble Nou Km 5.5, 43540 Tarragona, Spain; patricia.prado@irta.cat

* Correspondence: rln3@gcloud.ua.es (R.L.-N.); federico.lopez@ua.es (F.L.-M.)

Citation: Lopez-Nuñez, R.; Cortés Melendreras, E.; Giménez

Casalduero, F.; Prado, P.;

Lopez-Moya, F.; Lopez-Llorca, L.V.

Detection of Haplosporidium pinnae

from Pinna nobilis Faeces. J. Mar. Sci.

Eng. 2022, 10, 276. https://doi.org/

$10.3390 /$ jmse10020276

Academic Editor: Damien Tran

Received: 22 December 2021

Accepted: 14 February 2022

Published: 17 February 2022

Publisher's Note: MDPI stays neutral with regard to jurisdictional claims in published maps and institutional affiliations.

Copyright: () 2022 by the authors. Licensee MDPI, Basel, Switzerland. This article is an open access article distributed under the terms and conditions of the Creative Commons Attribution (CC BY) license (https:// creativecommons.org/licenses/by/ $4.0 /)$.

\begin{abstract}
Pinna nobilis (Linnaeus, 1758) is the largest bivalve endemic to the Mediterranean. It is distributed in a wide range of coastal environments, including estuaries. Pinna nobilis has recently become a critically endangered species (with almost $100 \%$ mortality) along the entire Spanish Mediterranean coast. This may be due to coinfections caused by Haplosporidium pinnae and bacterial pathogens such as Mycobacterium spp. We extensively sampled P. nobilis from Mar Menor lagoon (SE Spain), a site where individuals still survive. Using conventional PCR, we found Haplosporidium spp. in 7.1\% of mantle and faecal DNA samples in different individuals of $P$. nobilis. We identified and quantified Haplosporidium pinnae in P. nobilis using Sanger sequencing and qPCR. Faecal H. pinnae detection is non-invasive, unlike biopsies. Therefore, this non-lethal and non-invasive sampling method could contribute to the welfare of living populations, particularly in eutrophic environments, where they are prone to septicaemia. The use of faecal DNA analysis could be a major advance in epidemiology and recovery assessment studies of $P$. nobilis.
\end{abstract}

Keywords: Pinna nobilis; Haplosporidium pinnae; Mar Menor; PCR; faecal DNA

\section{Introduction}

Pinna nobilis (Linnaeus, 1758), or fan mussel, is a large, endemic Mediterranean bivalve distributed across a wide range of coastal environments, including estuaries [1]. In open coastal waters, the distribution and abundance of $P$ nobilis is closely associated with that of Posidonia oceanica seagrass meadows [2,3]. However, this species also inhabits coastal lagoons and estuarine bays dominated by other seagrasses, such as Cymodocea nodosa and Zostera spp. [4,5]. P. nobilis populations in both types of habitats are exposed to extreme environmental conditions that may influence their abundance, distribution, age structure and overall vulnerability [4].

Pinna nobilis was listed as a "critically endangered species" by the Spanish government in 2018 [6]. Mortalities of close to 100\% have been recorded along the whole Spanish Mediterranean coast [7]. This has been attributed to a disease mainly caused by the protozoa Haplosporidium pinnae [8] and bacterial pathogens such as Mycobacterium spp. and Vibrio spp. [9,10]. In January 2020, a population of P. nobilis located in Fangar Bay (northern Ebro River hemidelta) was pathogen-free and subject to salinities (30.5-33.5) lower than other Mediterranean areas. However, individuals were very vulnerable to the Storm Gloria, which decreased salinity in the area and caused $60 \%$ mortality in 3 weeks and $\sim 100 \%$ mortality in 6 weeks [4]. In 2018, the Alfacs Bay population, located a few kilometres further south (southern Ebro River hemidelta), was infected in its outermost area, located next to the open sea and subjected to higher salinities [4]. The other remaining P. nobilis population is in the Mar Menor lagoon (SE Spain). P. nobilis appeared in the lagoon and became an important part of the benthos. A mass mortality event occurred in 2016, which 
truncated $P$. nobilis colonisation and development, possibly because of the environmental collapse that occurred in the lagoon during that year [11]. In 2019, other authors identified ca. $14 \%$ of $P$. nobilis individuals infected by $H$. pinnae in the Mar Menor lagoon [12].

Obtaining enough high-quality tissue samples for DNA extraction from wild endangered animals is difficult. We tested several methods used for extracting DNA from bivalves and other animal tissues. Tissue-collection methods are often invasive. DNA from faeces is easy to obtain non-invasively [13]. DNA analysis in stools has been largely focused on gut microbiota and their relationship to health and disease. Bacterial and other non-host species DNA predominate in such samples [14]. Analysis of P. nobilis faecal DNA avoids harming the animal when detecting $H$. pinnae.

Our main objective in this work is the early detection of the pathogen Haplosporidium pinnae in individuals from the Mar Menor lagoon (SE Spain) using faecal samples, a noninvasive technique. For this purpose, we optimized DNA extraction from healthy and symptomatic $P$. nobilis. We used PCR/Sanger sequencing to detect the pathogen $H$. pinnae in mantle and faeces of $P$. nobilis. We also quantified H. pinnae in P. nobilis using qPCR [15].

\section{Materials and Methods}

\subsection{Collection of Biological Materials}

Mytilus edulis individuals were obtained fresh from a local supermarket to test DNA extraction and PCR protocols. Pinna nobilis samplings were carried out with the permission of regional authorities (Murcia regional government of Water, Agriculture, Farming, Fisheries and Environment; INF/2020/0017). P. nobilis samples and specimens were mostly collected from Mar Menor lagoon (SE Spain, Figure 1) by scuba diving at depths between 1.5 and $2.5 \mathrm{~m}$ (Table 1). Specimens were either processed directly after sampling or maintained in seawater tanks from the University of Murcia Aquarium prior to processing. Mantle biopsies $\left(0.5 \mathrm{~cm}^{2}\right.$ tissue) were performed axenically using bite forceps with no wooden stick (modified from [16]). P. nobilis faeces collection was carried out by vacuuming using $100 \mathrm{~mL}$ sterile syringes. Faeces were fixed in absolute alcohol for subsequent analyses.

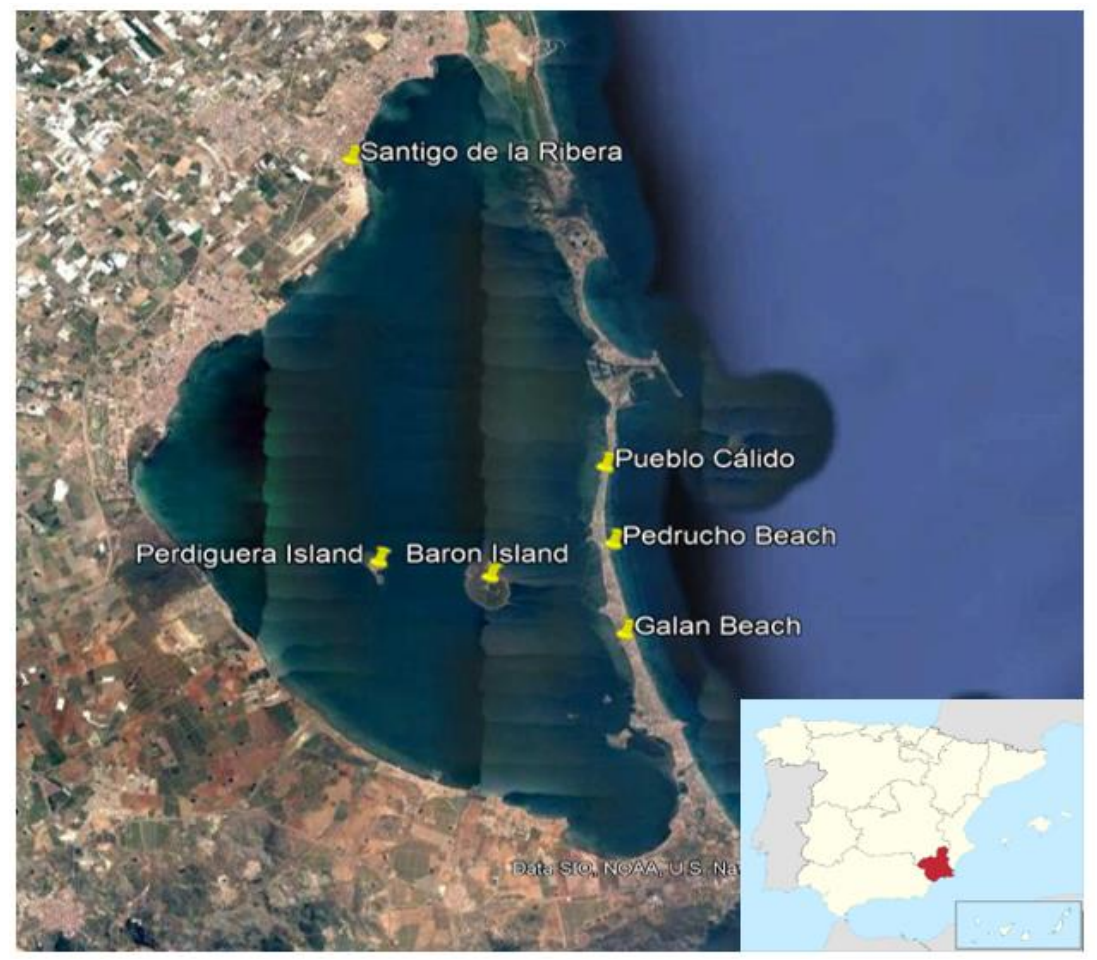

Figure 1. Pinna nobilis sampling sites (Mar Menor, SE Spain). 
Table 1. DNA samples analysed in this study.

\begin{tabular}{|c|c|c|c|c|c|c|}
\hline $\begin{array}{l}\text { Sample } \\
\text { Code }\end{array}$ & Date & Location & Sample & $\begin{array}{l}\text { DNA Extraction } \\
\text { Method }\end{array}$ & $\begin{array}{c}\text { PCR } \\
\text { (HapF1/HapR2) }\end{array}$ & $\begin{array}{c}\text { PCR } \\
\text { (LCOI1490/HC02198) }\end{array}$ \\
\hline M1 & FEB-2021 & Local Supermarket & \multirow{4}{*}{$\begin{array}{l}\text { Mytilus edulis } \\
\text { (Mantle necropsy) }\end{array}$} & СТАВ & nt & nt \\
\hline M2 & FEB-2021 & Local Supermarket & & $\begin{array}{c}\text { DNeasy PowerSoil } \\
\text { Pro Kit }\end{array}$ & $\mathrm{nt}$ & nt \\
\hline M3 & FEB-2021 & Local Supermarket & & $\begin{array}{l}\text { DNeasy Mini Plant } \\
\text { Kit }\end{array}$ & nt & nt \\
\hline M4 & FEB-2021 & Local Supermarket & & $\begin{array}{l}\text { DNeasy Blood \& } \\
\text { Tissue Kit }\end{array}$ & nt & nt \\
\hline PN1.1 & JUL-2021 & Pueblo Cálido (Mar Menor) & \multirow{15}{*}{$\begin{array}{c}\text { Pinna nobilis } \\
\text { (Mantle biopsy) }\end{array}$} & СТАВ & nt & nt \\
\hline PN1.2 & JUL-2021 & Pueblo Cálido (Mar Menor) & & $\begin{array}{c}\text { DNeasy PowerSoil } \\
\text { Pro Kit }\end{array}$ & nt & nt \\
\hline PN1.3 & JUL-2021 & Pueblo Cálido (Mar Menor) & & $\begin{array}{l}\text { DNeasy Mini Plant } \\
\text { Kit }\end{array}$ & $\mathrm{nt}$ & nt \\
\hline PN1.4 & JUL-2021 & Pueblo Cálido (Mar Menor) & & $\begin{array}{l}\text { DNeasy Blood \& } \\
\text { Tissue Kit }\end{array}$ & $\mathrm{nt}$ & nt \\
\hline PNE 1 & JUL-2021 & Perdiguera Island NW (Mar Menor) & & \multirow{34}{*}{$\begin{array}{l}\text { DNeasy Blood \& } \\
\text { Tissue Kits }\end{array}$} & $\mathrm{nt}$ & nt \\
\hline CP1 & FEB-2020 & Perdiguera Island NW (Mar Menor) & & & nt & nt \\
\hline $\mathrm{CP2}$ & FEB-2020 & Perdiguera Island SW (Mar Menor) & & & $\mathrm{nt}$ & nt \\
\hline $\mathrm{CP} 4$ & FEB-2020 & Perdiguera Island SW (Mar Menor) & & & nt & $\mathrm{nt}$ \\
\hline PN1 & FEB-2020 & Perdiguera Island SW (Mar Menor) & & & - & + \\
\hline PN2 & FEB-2020 & Baron Island (Mar Menor) & & & - & + \\
\hline PN3 & FEB-2020 & Baron Island (Mar Menor) & & & - & + \\
\hline PN5 & MAY-2020 & Santiago de la Ribera (Mar Menor) & & & - & + \\
\hline PN6 & MAY-2020 & Baron Island (Mar Menor) & & & - & + \\
\hline PN7 & MAY-2020 & Baron Island (Mar Menor) & & & - & + \\
\hline PN8 & MAY-2020 & Baron Island (Mar Menor) & & & - & + \\
\hline PN9 & JUN_2020 & Pueblo Cálido (Mar Menor) & \multirow{13}{*}{$\begin{array}{c}\text { Pinna nobilis } \\
\text { (Mantle necropsy } \\
\text { and digestive gland) }\end{array}$} & & + & + \\
\hline PN10 & JUN_2020 & Pueblo Cálido (Mar Menor) & & & - & + \\
\hline PN11 & JUN_2020 & Baron Island (Mar Menor) & & & - & + \\
\hline PN12 & JUN_2020 & Baron Island (Mar Menor) & & & - & + \\
\hline PN13 * & JUL_2020 & IRTA (Delta del Ebro) & & & + & + \\
\hline PN14* & JUL_2020 & IRTA (Delta del Ebro) & & & + & + \\
\hline PN16 & APR-2021 & Baron Island (Mar Menor) & & & - & + \\
\hline PN17 & APR-2021 & Baron Island (Mar Menor) & & & - & + \\
\hline PN18 & APR-2021 & Perdiguera Island NW (Mar Menor) & & & - & + \\
\hline PN19 & APR-2021 & Perdiguera Island NW (Mar Menor) & & & - & + \\
\hline PN20 & APR-2021 & Perdiguera Island SW (Mar Menor) & & & - & + \\
\hline PN21 & APR-2021 & Baron Island (Mar Menor) & & & - & + \\
\hline PN22 & APR-2021 & Baron Island (Mar Menor) & & & - & + \\
\hline PN15 & FEB-2020 & Perdiguera Island NW (Mar Menor) & \multirow{10}{*}{$\begin{array}{l}\text { Pinna nobilis } \\
\text { (Faeces) }\end{array}$} & & - & + \\
\hline PN4 & MAY-2020 & Baron Island (Mar Menor) & & & + & + \\
\hline PN 23 ** & APR-2021 & Galan beach (Mar Menor) & & & $\mathrm{nt}$ & + \\
\hline PN $24 * *$ & APR-2021 & Galan beach (Mar Menor) & & & nt & + \\
\hline PN25 & OCT-2021 & El Pedrucho (Mar Menor) & & & - & - \\
\hline PN26 & OCT-2021 & El Pedrucho (Mar Menor) & & & - & - \\
\hline PN27 & OCT-2021 & El Pedrucho (Mar Menor) & & & - & - \\
\hline PN28 & OCT-2021 & El Pedrucho (Mar Menor) & & & - & - \\
\hline PN29 & OCT-2021 & El Pedrucho (Mar Menor) & & & - & - \\
\hline PN30 & OCT-2021 & El Pedrucho (Mar Menor) & & & - & + \\
\hline
\end{tabular}

Abbreviations: $\mathrm{nt}=$ non tested + indicates positive in PCR amplification-indicates no PCR hybridisation $\left({ }^{*}\right)$ Positive control from IRTA (Delta del Ebro, Spain). ${ }^{* *}$ Samples amplified with HPNF3/HPNR3 primers for Haplosporidium pinnae for PCR primers. 


\subsection{DNA Extraction}

Four DNA extraction methods were tested for M. edulis and P. nobilis samples. For the CTAB-based DNA extraction method, we followed [17], with modifications as follows. Samples were crushed in liquid nitrogen and added to buffer A (1.65 M sorbitol, $50 \mathrm{mM}$ MES (sulphonic acid), pH 6.1, 10 mM EDTA, 2 (w/v) PVP-40, 0.1\% (w/v) BSA (bovine serum albumin) and $5 \mathrm{mM}$ B-mercaptoethanol) while shaking for 2-3 min. The mixture was filtered through Miracloth ${ }^{\circledR}$ (SIGMA-Aldrich, Darmstadt, Germany) and centrifuged at $3000 \times g$ for $2 \mathrm{~min}$. Buffer A was then removed, pellets were resuspended in buffer B (buffer A without PVP) and centrifuged at $3000 \times g$ for $2 \mathrm{~min}$. Buffer B was discarded, and pellets were resuspended in a CTAB-based DNA extraction buffer ( $300 \mu \mathrm{L}$ CTAB $2 \%, 30 \mu \mathrm{L} 10 \%$ Tween 20 and $3 \mu \mathrm{L}$ Proteinase $\mathrm{K}(20 \mu \mathrm{g} / \mu \mathrm{L}))$. Samples were incubated on ice for $1 \mathrm{~h}$ and then centrifuged at $15,000 \times g$ for $10 \mathrm{~min}$. The aqueous phase was transferred to new tubes for 5 min extraction with phenol, chloroform and isoamyl alcohol and then centrifuged. This step was performed again without phenol for $2 \mathrm{~min}$. The DNA was treated with isopropyl alcohol at $-20^{\circ} \mathrm{C}$ on ice for $20 \mathrm{~min}$. After centrifugation for $10 \mathrm{~min}$, the supernatant was discarded, and the pellet was washed with ethanol at $-20^{\circ} \mathrm{C}$. Pellets containing DNA were resuspended in nuclease-free water and stored at $-80^{\circ} \mathrm{C}$. DNeasy PowerSoil Pro, DNeasy Mini Plant and DNeasy blood and tissue kits were also used, following instructions provided by the manufacturer (Qiagen, Germantown, MD, USA) (Table 1). Isolated DNA was evaluated spectrophotometrically using Nanodrop One (Thermo Scientific, Waltham, MA, USA).

\subsection{Gene Amplification and Sequencing}

Primers used for the detection of Haplosporidium sp. (including H. pinnae) in Pinna nobilis (Table 2) were used with samples fixed in ethanol (SIGMA-Aldrich, Darmstadt, Germany). Total genomic DNA was isolated from healthy and symptomatic hosts. PCR reactions included a pre-heating step of $10 \mathrm{~min}$ at $94{ }^{\circ} \mathrm{C}, 35$ cycles of $1 \mathrm{~min}$ at $94{ }^{\circ} \mathrm{C}, 1 \mathrm{~min}$ at $49^{\circ} \mathrm{C}$ and $1 \mathrm{~min}$ at $72{ }^{\circ} \mathrm{C}$, with a final extension of $10 \mathrm{~min}$ at $72{ }^{\circ} \mathrm{C}$. PCR reactions were repeated when required to supply enough DNA for Sanger sequencing. PCR products were run on $1 \%$ electrophoresis agarose gel. Haplosporidium sp.-positive Pinna nobilis DNA samples had amplicons, which were extracted from gels using a DNA purification kit (Qiagen, Germantown, MD, USA). Sanger sequencing of amplicons was carried out by Macrogen Inc. (Seoul, Korea) and by University of Alicante Technical Services (Spain). Consensus sequences were determined from data obtained using the LALIGN tool (https: //www.ebi.ac.uk/Tools/psa/lalign/, access on 22 November 2021) and Clustal $\Omega$ (https: //www.ebi.ac.uk/Tools/msa/clustalo/, access on 22 November 2021). High-similarity BLAST searches were performed for hits with the NCBI DNA sequence database. Primers used to confirm that the samples analysed belong to $P$. nobilis are shown in Table 2. PCR conditions for $P$. nobilis included 35 cycles of $1 \mathrm{~min}$ at $95^{\circ} \mathrm{C}, 1 \mathrm{~min}$ at $40^{\circ} \mathrm{C}$ and $1 \mathrm{~min}$ and $30 \mathrm{~s}$ at $72{ }^{\circ} \mathrm{C}$, with a final extension of $7 \mathrm{~min}$ at $72{ }^{\circ} \mathrm{C}$. Sequences obtained in this study were deposited in the NCBI database with accession numbers OM397480-OM397481 for Pinna nobilis and OM510393-OM510394-OM510395 for Haplosporidium pinnae. 
Table 2. Primers used in this study for PCR amplification of DNA from Haplosporidium pinnae and Pinna nobilis.

\begin{tabular}{|c|c|c|c|c|}
\hline Haplosporidium Primers & Sequence $\left(5^{\prime}-3^{\prime}\right)$ & Amplicon Size (bp) & $\operatorname{Tm}$ & Reference \\
\hline HapF1 & GTTCTTTCWTGATTCTATGMA & 331 & 49 & \multirow{4}{*}{ [18] } \\
\hline HapR2 & GATGAAYAATTGCAATCAYCT & 331 & 49 & \\
\hline HPNF3 & CATTAGCATGGAATAATAAAACACGAC & 600 & 55 & \\
\hline HPNR3 & GCGACGGCTATTTAGATGGCTGA & 600 & 55 & \\
\hline Pinna nobilis Primers & Sequence $\left(5^{\prime}-3^{\prime}\right)$ & Amplicon Size (bp) & $\operatorname{Tm}$ & Reference \\
\hline LCOI1490 & GGTCAACAAATCATAAAGATATTGG & 710 & 40 & \multirow{2}{*}{ [19] } \\
\hline HC02198 & TAAACTTCAGGGTGACCAAAAAATCA & 710 & 40 & \\
\hline
\end{tabular}

\section{4. qPCR Quantification of Haplosporidium Pinnae in Pinna Nobilis}

DNA was quantified using quantitative real-time polymerase chain reaction (qPCR) with SYBR Green and ROX kit (Roche, Basel, Switzerland). DNA quantification was performed in a StepOnePlus real-time PCR system (Applied Biosystems, Foster City, CA, USA). A calibration curve for qPCR was made from $10 \mathrm{pg}$ to $1 \times 10^{-4} \mathrm{pg}$ of a purified $331 \mathrm{bp}$ amplicon from Haplosporidium pinnae DNA obtained in this study. Two positive PCR samples for H. pinnae (PN13 and PN14) were also tested to quantify the presence of the pathogen in Pinna nobilis, together with a negative control (no DNA). All samples were run in triplicate. The qPCR run conditions were the same as for conventional PCR with the primers used for $H$. pinnae detection.

\section{Results}

\subsection{PCR Detection of Haplosporidium sp. in Pinna nobilis}

A Mytilus edulis DNA sample extracted with the CTAB method, displayed a highmolecular-weight band in the agarose gel electrophoresis (M1, Figure 2). This indicates that the method is suitable for extracting DNA from the bivalve. However, when tested with mantle samples, Pinna nobilis rendered no DNA (PN 1.1, Figure 2). Other methods also failed to extract DNA from mantle or resulted on its degradation and were therefore discarded (M2, M3, PN 1.2, PN 1.3, Figure 2). Pinna nobilis samples extracted with DNeasy Blood and Tissue kit rendered DNA of good quality (PN 1.4, Figure 2). This method was therefore adopted for DNA extraction from $P$. nobilis samples.

DNA was extracted from faeces (PN4, Figure 3) and a necropsy (PN 9, Figure 3) from P. nobilis individuals collected in Mar Menor (SE Spain, Table 1). Both samples displayed an amplification band of $331 \mathrm{bp}$ with Haplosporidium sp. primers. A band of similar size was obtained with DNA samples. PN13 and PN14 (mantle necropsy samples) from symptomatic $P$. nobilis individuals were used as a positive control for PCR detection of Haplosporidium sp. (Figure 3). A total of 28 P. nobilis individuals from the Mar Menor lagoon were analysed by PCR using Haplosporidium sp. primers. Two of them (7.1\%) were positive for the pathogen. 


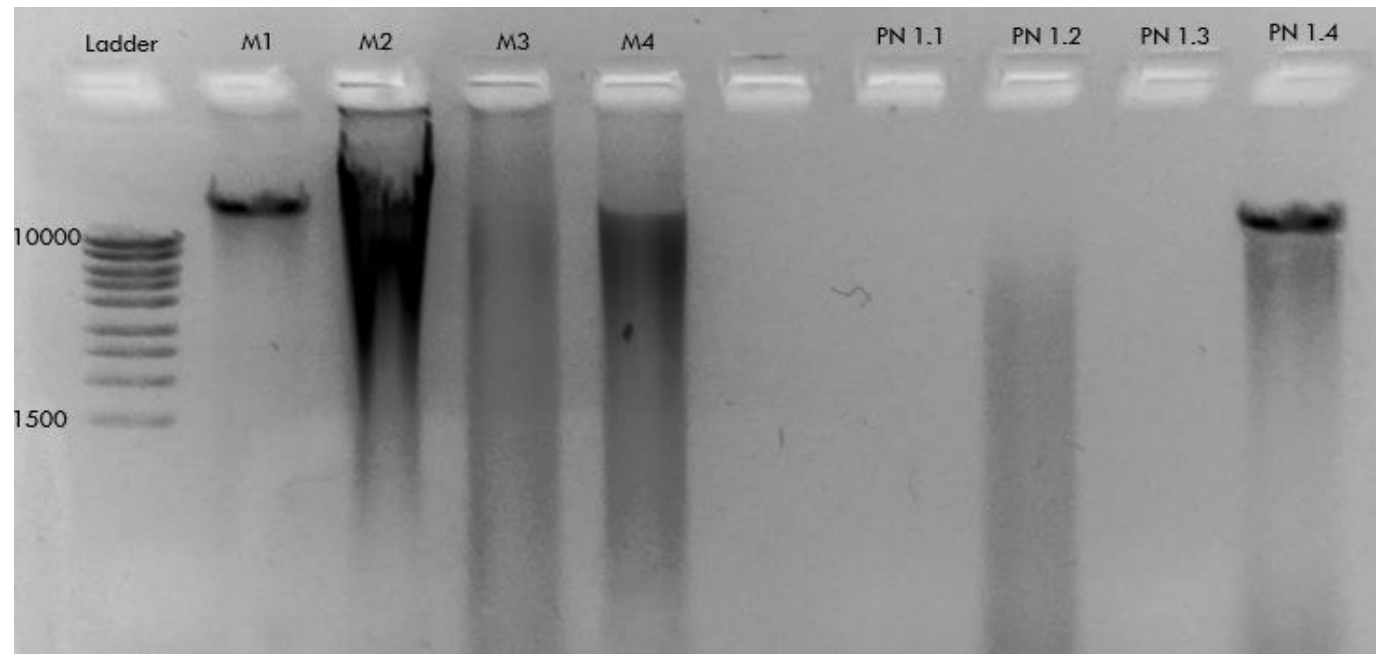

Figure 2. Agarose gel electrophoresis analysis of methods tested to extract DNA from Mytilus edulis (M) and Pinna nobilis (PN): CTAB (M1 and PN1.1), DNeasy PowerSoil Pro Kit (M2 and PN1.2) and DNeasy Plant Pro and Plant Kits (M3 and PN1.3), DNeasy Blood and Tissue Kit (M4 and PN1.4).

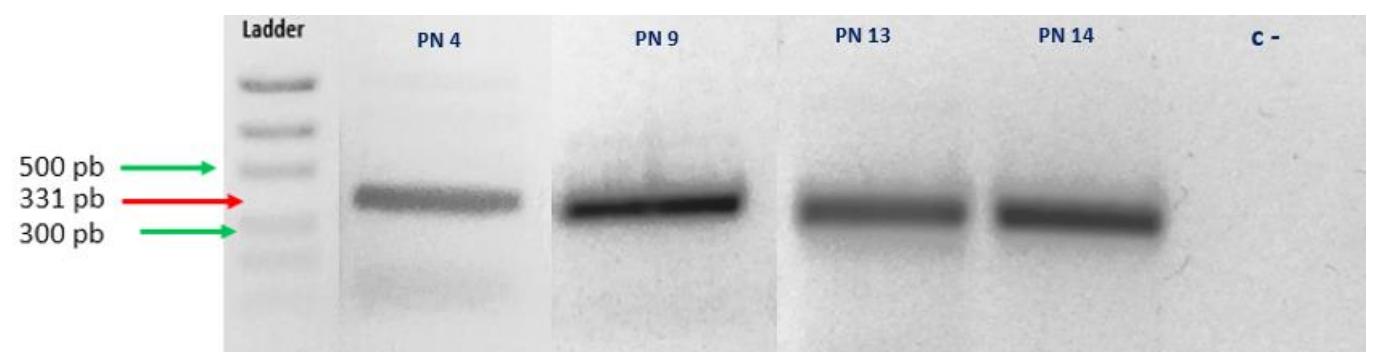

Figure 3. PCR test gel for the amplification of Haplosporidium sp.

3.2. Confirmation of Haplosporidium pinnae Infection of P. nobilis by Sanger Sequencing

P. nobilis faeces and mantle samples PCR-positive for Haplosporidium sp. (Table S1) were Sanger sequenced. BLAST analysis of all sequences (Table 3) showed high identity hits with Haplosporidium pinnae (Table 3).

Table 3. NCBI high-similarity blast analysis for Sanger sequences obtained from Pinna nobilis by Haplosporidium sp.-positive samples from PCR.

\begin{tabular}{cccc}
\hline Sample & $\begin{array}{c}\text { Most Similar } \\
\text { Species (BLAST) }\end{array}$ & Query Cover & Identity \\
\hline PN4 & $\begin{array}{c}\text { Haplosporidium pinnae } \\
(\text { MN689716.1) }\end{array}$ & $98 \%$ & $96.08 \%$ \\
\hline PN9 & $\begin{array}{c}\text { Haplosporidium pinnae } \\
(\text { MN689716.1) }\end{array}$ & $99 \%$ & $90.83 \%$ \\
\hline PN13 & $\begin{array}{c}\text { Haplosporidium pinnae } \\
\text { (MN689716.1) }\end{array}$ & $100 \%$ & $100 \%$ \\
\hline PN14 & $\begin{array}{c}\text { Haplosporidium pinnae } \\
\text { (MN689716.1) }\end{array}$ & $100 \%$ \\
\hline
\end{tabular}

A sample of three $P$. nobilis samples found negative for Haplosporidium sp. by PCR (Table S2) were amplified with (LCOI1490-HC02198) primers. Sanger sequencing confirmed samples belonged to Pinna nobilis (Table S3). 


\subsection{Quantification of Haplosporidium pinnae in Pinna nobilis}

Figure S1 shows P. nobilis PN13 and PN14 samples, positive for H. pinnae (ca.1 $\mathrm{gg}$ ), contained $7.3 \times 10^{-9}$ and $2.4 \times 10^{-10} \mathrm{pg}$ DNA, respectively, of the parasite. The other pathogen-positive samples (PN4 and PN9) could not be quantified with the small amount of DNA available, which was only enough for PCR detection and Sanger sequencing confirmation of H. pinnae in the samples.

\section{Discussion}

We extensively sampled P. nobilis in the Mar Menor lagoon (SE Spain). We performed several methods of DNA extraction from small ethanol-preserved samples (approx. $0.020 \mathrm{~g}$ ) of Pinna nobilis from the digestive gland, mantle and faeces. We made this choice of samples because infection of the epithelium of the host digestive gland tubules is very frequent in Haplosporidium species. These pathogens proliferate and sporulate in the hemocoel and connective tissue of the host. In P. nobilis, heavy infection of the digestive gland tubules profoundly interferes with food absorption, leading to starvation, severe general dysfunction and eventually death of the bivalve [20]. In this work, we were able to detect $H$. pinnae in the faeces and mantle of $P$. nobilis. The former method avoids damage and stress to the animal associated with tissue extraction. Our faecal DNA method should be optimized to minimize false-negative detection of pathogens in P. nobilis [13,14]. We also quantified $H$. pinnae by qPCR in P. nobilis. The higher sensitivity of qPCR compared to conventional PCR [15] allows for assessment of the effectiveness of practices (e.g., quarantine and antimicrobials) for reducing $H$. pinnae infection.

H. pinnae appears to be host-specific, since it is not detected in P. rudis, which occurs in the same areas and habitats where P. nobilis is severely infected [20]. It is still unknown how the parasite is transported in the marine environment. Spatial and temporal mortality data of $P$. nobilis on the coast of southern Spain suggest $H$. pinnae outbreaks spread following summer sea currents [21]. A comprehensive study of the complete life cycle of H. pinnae and how it spreads in the marine environment will help to implement ways to mitigate the disease and limit the spread of the pathogen. Non-invasive faecal PCR detection and quantification of $H$. pinnae might be a key tool to eliminate unnecessary risks in the survival of specimens during monitoring and rapid detection of pathogen threat of P. nobilis on the Spanish Mediterranean coast, especially in Mar Menor lagoon (Article 60.2 of Law 42/2007, Natural Heritage and Biodiversity).

\section{Conclusions}

The results obtained in this work are important for the early detection of the pathogen Haplosporidium sp. in Pinna nobilis, a protected species under severe danger of extinction.

- A kit for blood and tissue DNA extraction renders high-quality DNA from P. nobilis mantle/digestive epithelium and faeces samples.

- We detected Haplosporidium sp. in P. nobilis mantle and faeces using conventional PCR.

- Sanger sequencing confirmed H. pinnae in mantle and faeces of infected P. nobilis.

- About $7.1 \%$ of $P$. nobilis individuals $(n=28)$ from Mar Menor lagoon (SE Spain) are infected with $H$. pinnae.

- P. nobilis-infected individuals contain $2.4 \times 10^{-10}-7.3 \times 10^{-9} \mathrm{pg}$ H. pinnae DNA $\mu^{-1}$ tissue.

- P. nobilis faecal DNA analysis using PCR and qPCR can be used to monitor infection and recovery from $H$. pinnae.

Supplementary Materials: The following supporting information can be downloaded at: https: //www.mdpi.com/article/10.3390/jmse10020276/s1, Table S1: Pinna nobilis DNA samples PCR amplified with HapF1-HapR2 primers for Sanger sequencing. Table S2: Pinna nobilis DNA samples PCR amplified with COIH1-COIL1 primers. Table S3: Blast analysis for Sanger sequences obtained from PCR positive Pinna nobilis samples. Figure S1: Calibration curve for qPCR for quantification of Haplosporidium pinnae. 
Author Contributions: Investigation, methodology, formal analysis, writing (original draft) and visualization: R.L.-N.; sample collection: E.C.M., P.P. and F.G.C.; supervision, methodology and reviewing: F.L.-M.; supervision, methodology, writing (original draft), reviewing and funding acquisition: L.V.L.-L. All authors have read and agreed to the published version of the manuscript.

Funding: This research was funded by the project DGMARMENOR-MURCIA1-21T entitled: Study, Evaluation and Molecular Detection of Pathogenic Haplosporidium pinnae in Species of Pinna nobilis from Mar Menor and the Department of Marine Science and Applied Biology, the University of Alicante. Fondo Europeo de Desarrollo Regional Una manera de hacer Europa.

Institutional Review Board Statement: Not applicable.

Informed Consent Statement: Not applicable.

Data Availability Statement: Sequences obtained in this study were deposited in the NCBI database with accession numbers OM397480-OM397481 for Pinna nobilis and OM510393-OM510394-OM510395 for Haplosporidium pinnae.

Acknowledgments: We would like to thank M.U.C, Cristina Mingot Ureta, from the Department of Marine Science and Applied Biology (University of Alicante) for her technical support. This study was carried out in collaboration with the "Proyecto Banco de Especies Protegidas y Singulares del Mar Menor" S/Ref. Decreto 65/ /2020. Dirección General del Mar Menor, de la Consejería de Agua, Agricultura, Ganadería, Pesca y Medio Ambiente (Murcia Goverment) in co-operation with the Murcia University Aquarium. The authors are also grateful to the Biodiversity Foundation of the Ministry for Ecological Transition and the Demographic Challenge for supporting the Recupera Pinna project in the 2020 call for proposals.

Conflicts of Interest: The authors declare no conflict of interest. The funders had no role in the design of the study; in the collection, analyses, or interpretation of data; in the writing of the manuscript, or in the decision to publish the results.

\section{References}

1. Butler, A.; Vicente, N.; de Gaulejac, B. Ecology of the pterioid bivalves Pinna bicolor Gmelin and Pinna nobilis L. Mar. Life 1993, 3, 37-45.

2. Zavodnik, D. Contribution to the Ecology of Pinna nobilis L. (Moll. bivalvia) in the Northern Adriatic. JAZU (Yugoslav Academy of Sciences and Arts (Jugoslavenska akademija znanosti i umjetnosti) 1967. Available online: https://scholar.google.com/ scholar_lookup?title=Contribution+to+the+ecology+of+Pinna+nobilis+L.+(Moll.+Bivalvia) + in +the+Northern+Adriatic+sea\& author=Zavodnik+D.\&publication+year=1967\&journal=Thalassia+Jugoslavica\&volume=3\&pages=93-102 (accessed on 21 December 2021).

3. Zavodnik, D.; Hrs-Brenko, M.; Legac, M. Synopsis on the fan shell Pinna nobilis L. in the eastern Adriatic Sea. In Les Espèces Marines à Protéger en Méditerranée; Boudourescque, C.F., Avon, M., Gravez, V., Eds.; GIS Posidonie: Marseilles, France, 1991; pp. 169-178.

4. Prado, P.; Grau, A.; Catanese, G.; Cabanes, P.; Carella, F.; Fernández-Tejedor, M.; Añón, K.T.; Hernandis, S.; Tena, J.; García-March, J.R. Pinna nobilis in suboptimal environments are more tolerant to disease but more vulnerable to severe weather phenomena. Mar. Environ. Res. 2021, 163, 105220. [CrossRef] [PubMed]

5. Kersting, D.; Benabdi, M.; Čižmek, H.; Grau, A.; Jimenez, C.; Katsanevakis, S.; Öztürk, S.; Tuncer, L.; Tunesi, M.; Vázquez-Luis, N.; et al. Pinna nobilis. The IUCN Red List of Threatened Species. 2019, 2019-3. Available online: https:/ / www.iucnredlist.org/ species/160075998/160081499 (accessed on 21 December 2021).

6. García-March, J.; Tena, J.; Henandis, S.; Vázquez-Luis, M.; López, D.; Téllez, C.; Prado, P.; Navas, J.I.; Bernal, J.; Catanese, G.; et al. Can we save a marine species affected by a highly infective, highly lethal, waterborne disease from extinction? Biol. Conserv. 2020, 243, 108498. [CrossRef]

7. Orden TEC/1078/2018. Por la Que se Declara la Situación Crítica de Cistus Heterophyllus Subsp. Carthaginensis, Lanius Minor, Margaritifera Auricularia, Marmaronetta Angustirostris, Mustela Lutreola, Pinna nobilis y Tetrao Urogallus Cantabricus En España, y se Declaran de Interés General Las Obras y Proyectos Encaminados a la Recuperación de Dichos Taxones. Boletin Oficial de Estado (BOE). 28 September 2018. Available online: https://www.boe.es/eli/es/o/2018/09/28/tec1078 (accessed on 21 December 2021).

8. Cabanellas-Reboredo, M.; Vázquez-Luis, M.; Mourre, B.; Álvarez, E.; Deudero, S.; Amores, Á.; Addis, P.; Ballesteros, E.; Barrajón, A.; Coppa, S.; et al. Tracking a mass mortality outbreak of pen shell Pinna nobilis populations: A collaborative effort of scientists and citizens. Sci. Rep. 2019, 9, 1335. [CrossRef] [PubMed]

9. Carella, F.; Aceto, S.; Pollaro, F.; Miccio, A.; Iaria, C.; Carrasco, N.; Prado, P.; De Vico, G. A mycobacterial disease is associated with the silent mass mortality of the pen shell Pinna nobilis along the Tyrrhenian coastline of Italy. Sci. Rep. 2019, 9, 2725. [CrossRef] [PubMed] 
10. Lattos, A.; Bitchava, K.; Giantsis, I.; Theodorou, J.; Batargias, C.; Michaelidis, B. The Implication of Vibrio Bacteria in the Winter Mortalities of the Critically Endangered Pinna nobilis. Microorganisms 2021, 9, 922. [CrossRef] [PubMed]

11. Giménez-Casalduero, F.; Gomariz-Castillo, F.; Alonso-Sarría, F.; Cortés, E.; Izquierdo-Muñoz, A.; Ramos-Esplá, A. Pinna nobilis in the Mar Menor coastal lagoon: A story of colonization and uncertainty. Mar. Ecol. Prog. Ser. 2020, 652, 77-94. [CrossRef]

12. Nebot-Colomer, E.; Álvarez, E.; Belando, M.D.; Deudero, S.; Catanese, G.; Bernardeau-Esteller, J.; García-Muñoz, R.; RamosSegura, A.; Ruiz, J.M.; Vázquez-Luis, M. Living under threat: Will one of the last Pinna nobilis populations be able to survive? Aquat. Conserv. Mar. Freshw. Ecosyst. 2021, 32, 1-13. [CrossRef]

13. Chiou, K.L.; Bergey, C.M. Methylation-based enrichment facilitates low-cost, noninvasive genomic scale sequencing of populations from feces. Sci. Rep. 2018, 8, 1975. [CrossRef] [PubMed]

14. He, K.; Fujiwara, H.; Zajac, C.; Sandford, E.; Reddy, P.; Choi, S.W.; Tewari, M. A Pipeline for Faecal Host DNA Analysis by Absolute Quantification of LINE-1 and Mitochondrial Genomic Elements Using ddPCR. Sci. Rep. 2019, 9, 5599. [CrossRef] [PubMed]

15. López-Sanmartín, M.; Catanese, G.; Grau, A.; Valencia, J.M.; García-March, J.R.; Navas, J.I. Real-Time PCR based test for the early diagnosis of Haplosporidium pinnae affecting fan mussel Pinna nobilis. PLoS ONE 2019, 14, e0212028. [CrossRef] [PubMed]

16. Sanna, D.; Cossu, P.; Dedola, G.L.; Scarpa, F.; Maltagliati, F.; Castelli, A.; Franzoi, P.; Lai, T.; Cristo, B.; Curini-Galletti, M.; et al. Mitochondrial DNA Reveals Genetic Structuring of Pinna nobilis across the Mediterranean Sea. PLoS ONE 2013, 8, e67372. [CrossRef] [PubMed]

17. Jódar-Pérez, A.B.; Terradas-Fernández, M.; López-Moya, F.; Asensio-Berbegal, L.; López-Llorca, L.V. Multidisciplinary Analysis of Cystoseira sensu lato (SE Spain) Suggest a Complex Colonization of the Mediterranean. J. Mar. Sci. Eng. 2020, 8, 961. [CrossRef]

18. Renault, T.; Stokes, N.; Chollet, B.; Cochennec, N.; Berthe, F.; Gerard, A.; Burreson, E. Haplosporidiosis in the Pacific oyster Crassostrea gigas from the French Atlantic coast. Dis. Aquat. Org. 2000, 42, 207-214. [CrossRef] [PubMed]

19. Folmer, O.; Black, M.; Hoeh, W.; Lutz, R.; Vrijenhoek, R. DNA primers for amplification of mitochondrial cytochrome c oxidase subunit I from diverse metazoan invertebrates. Mol. Mar. Biol. Biotechnol. 1994, 3, 294-299. [PubMed]

20. Catanese, G.; Grau, A.; Valencia, J.; March, J.R.G.; Vázquez-Luis, M.; Alvarez, E.; Deudero, S.; Darriba, S.; Carballal, M.J.; Villalba, A. Haplosporidium pinnae sp. nov., a haplosporidan parasite associated with mass mortalities of the fan mussel, Pinna nobilis, in the Western Mediterranean Sea. J. Invertebr. Pathol. 2018, 157, 9-24. [CrossRef] [PubMed]

21. Fernández, V.; Dietrich, D.E.; Haney, R.L.; Tintoré, J. Mesoscale, seasonal and interannual variability in the Mediterranean Sea using a numerical ocean model. Prog. Oceanogr. 2005, 66, 321-340. [CrossRef] 